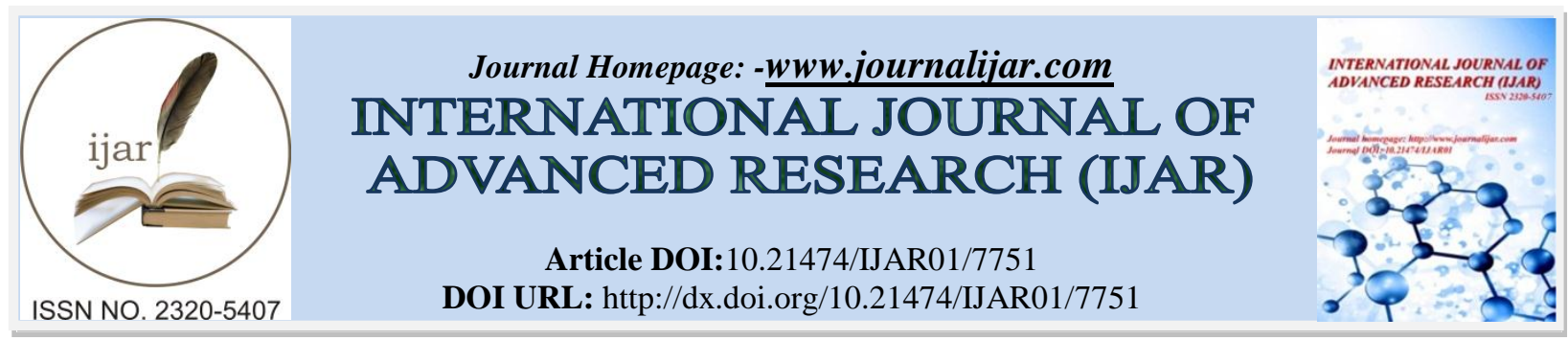

RESEARCH ARTICLE

\title{
IN VITRO CYTOTOXIC AND ANTIPROLIFERATIVE ACTIVITIES OF UVARIA NARUM SEED OIL (UNSO).
}

Smitha K. Ramavarma, Ansa P. Unnikrishnan, Babu. T. Devassy and Achuthan C. Raghavamenon. Dept. of Biochemistry, Amala Cancer Research Centre, Recognized by University of Calicut, Amala Nagar, Thrissur-680 555 Amala Nagar P.O., Thrissur, Kerala- 680555.

\section{Manuscript Info}

Manuscript History

Received: 23 July 2018

Final Accepted: 29 August 2018

Published: September 2018

Keywords:-

Uvaria narum seed oil, cytotoxicity, antiproliferative activity.

\section{Abstract}

Annonaceae family plants are well known for its biologically active phytochemicals with cytotoxic and anticancer potential. Uvaria narum has traditional use in rheumatism, jaundice, biliousness, and fevers. The root bark of this plant yields an essential oil used in Indian traditional medicine for erysipelas, eczema, fever, biliousness, and rheumatism. The plant is locally available but less explored scientifically. In the present investigation, U. narum seed oil (UNSO) was found to be cytotoxic to Dalton's Lymphoma Ascites cells (DLA) with $\mathrm{IC}_{50}$ value $77 \pm 5.37 \mu \mathrm{g} / \mathrm{mL}$ and Ehrlich Ascites Carcinoma cells (EAC) (100 $\mu \mathrm{g} / \mathrm{mL}$ ) in short-term in vitro cytotoxicity assay while less toxic to normal spleen cells ( $\mathrm{IC}_{50}$ values above $100 \pm 1.41 \mu \mathrm{g} / \mathrm{mL}$ ). Further in Vero (normal monkey kidney cells), HCT-15 (Human colorectal adenocarcinoma cells) and HepG2 (Hepatocellular carcinoma cells) and HeLa cells (Human cervical carcinoma cells) in culture exposed to UNSO at varied concentrations displayed a dose-dependent reduction in cell viability indicating its anti-proliferative potential. The concentration required for $50 \%$ loss in viability $\left(\mathrm{IC}_{50}\right)$ were $48.05 \pm$ $2.43,40.0 \pm 1.94,50.30 \pm 1.45$ and $100 \pm 2.35 \mu \mathrm{g} / \mathrm{mL}$, respectively. Further purifications of UNSO may yield pharmacologically important phytochemicals.

Copy Right, IJAR, 2018, All rights reserved.

\section{Introduction:-}

The phytochemical research over the past, based on the ethnopharmacological information has led to the discovery of new cytotoxic and antiproliferative agents from higher plants. Taxol and Podophyllotoxin are found to be beneficial in the treatment of refractory ovarian, breast and other cancers (Demain and Vaishnav 2011). Synthetic modification of these drugs led to the development of etoposide reported being effective for small cell cancers of the lungs and testes (Mukherjee et al. 2001). Camptothecin, a topoisomerase inhibitor isolated from Camptotheca acuminata have been extensively used in cancer therapy (Bissery et al. 1996). Many other important plant-derived anticancer compounds have been in clinical use such as vincristine, vinblastine, colchicine, ellipticine, lepachol and rohitukine (Mukherjee et al. 2001).

Acetogenins, styryl-lactones, and polyoxy-cyclohexenoids are the potent antitumor phytochemical identified from Annonaceae plants (Yang et al. 2000). Uvaricin and uvaretin, purified from the root extracts of Uvaria accuminata 
(Annonaceae) are known to have antitumor activity (Dai et al. 2012; Cole et al. 1976). Uvaria narum (Dunal) Wall., a plant under Annonaceae is not extensively studied for its biological properties. Uvaria narum Wall is widely distributed in Western Ghats of India and is popularly used in ethnomedicine. Root extract is medicinally employed as a possible antioxidant and anti-bactericidal (Reddy et al. 2012). However, the seeds have never been studied for pharmacological activities. Herein, we analyzed the efficacy of $U$. narum Wall. seed oil for its cytotoxic and antiproliferative activities.

\section{Materials and methods:- Chemicals}

Trypan blue was purchased from Spectrum Pvt. Ltd., India, and 3-(4, 5-dimethylthiazol-2-yl)-2, 5diphenyltetrazolium bromide (MTT) from Sisco Research Laboratories Pvt. Ltd., Mumbai, India. Dextrose and isopropanol were purchased from Merck chemical Ltd. India. Streptomycin and Penicillin were procured from HiMedia laboratories, Mumbai. Trypsin was purchased from Life Technologies, UK. Rosewell park memorial institute medium and Dulbecco's modified eagle medium were obtained from Gibco, Life technologies, Banglore. All other chemicals and reagents used were of analytical grade.

\section{Collection of $U$.narum seeds and oil extraction}

Uvaria narum was collected from Thrissur district, Kerala and authenticated by Dr. C.N. Sunil, Associate professor, Department of Botany, Sree Narayana Mangalam College (SNMC), Maliankara, Ernakulam, Kerala. A voucher specimen was maintained (Voucher No. ACRC203). Seeds of this plant were utilized in the study.

\section{Preparation of seed oil}

Approximately, 20-25g of U. narum seeds were air dried, weighed and powdered. The seed powder was then extracted using $95 \%$ ethanol and $5 \%$ (w/v) water suspension. The supernatant was collected by centrifugation (3000 rpm, 45min) and kept for evaporation at room temperature. The residue thus obtained was again extracted using nhexane $(150 \mathrm{~mL})$. The supernatant was collected by centrifugation (3000 rpm, 15min). Oil portion separated were redissolved in ethanol and used for further studies.

\section{Short term in vitro cytotoxicity analysis Tumor cell lines} Ehrlich Ascites Carcinoma (EAC) and Dalton's Lymphoma Ascites (DLA) cells were maintained in the peritoneal cavity of mice at the animal house facility of Amala cancer research Centre. The cells were aspirated from the peritoneal cavity and washed with saline $1 \times 10^{6}$ cells/ $\mathrm{ml} \mathrm{PBS}$ were used in the study.

HeLa (Human cervical carcinoma), HepG2 (Human hepatocarcinoma), HCT-15 (Human colorectal adenocarcinoma) and Vero (African monkey kidney) cell lines were obtained from the National Centre for Cell Science (NCCS), Pune, India. Each cell line was maintained in its appropriate medium supplemented with $10 \%$ FBS and antibiotics and incubated at $37^{\circ} \mathrm{C}$ under a $5 \% \mathrm{CO}_{2}$ atmosphere.

\section{Normal Splenocytes}

Male Sprague - Dawley rat weighing 250-310 g were anaesthetized and dissected. The spleen was removed and collected in a sterile nylon sieve over a Petri dish half filled with PBS. The spleen was gently pressed through the sieve using a plunger, all the while adding PBS on the spleen to keep the cells moist. The disaggregated splenocytes were transferred to a test tube and centrifuged at 2,000 rpm for $5 \mathrm{~min}$. The cell pellet was re-suspended in PBS and counted in a hemocytometer.

\section{Methods:-}

\section{In vitro cytotoxicity assay}

Cells were aspirated from the peritoneal cavity of mice and freed from debris. A stock cell suspension was prepared in PBS $\left(1 \times 10^{7}\right.$ cells $\left./ \mathrm{mL}\right)$. The viability of cells was checked using Trypan blue stain method (Talwar, 1974). The assay system contained $1 \times 10^{6}$ cells and different concentrations $(10-100 \mu \mathrm{g} / \mathrm{mL})$ of the drugs in a total volume of $1 \mathrm{~mL}$ and incubated at $37^{\circ} \mathrm{C}$ for $3 \mathrm{hr}$. Control tubes contained only cell suspension without any additives. At the end of incubation, $0.1 \mathrm{~mL}$ of $1 \%$ trypan blue was added and kept for 2-3 min and loaded onto a hemocytometer to determine the number of dead cells. 


\section{In vitro antiproliferative activity using MTT assay}

Anti-proliferative activity of UNSO (dissolved in ethanol) was evaluated in HeLa, HepG2, HCT-15, and Vero cell lines, using the MTT assay. Cells $\left(1 \times 10^{5}\right.$ cells $\left./ \mathrm{mL}\right)$ were seeded in 12 well plates and incubated at $37^{\circ} \mathrm{C}$ under a $5 \%$ $\mathrm{CO}_{2}$ and $95 \%$ humid atmosphere. After reaching $90 \%$ confluence, the medium was replaced with fresh medium containing different concentrations $(5-100 \mu \mathrm{g} / \mathrm{mL})$ of individual extracts. Cells were then allowed to grow for $48 \mathrm{hr}$ following which the spent medium was replaced with fresh medium containing $100 \mu 1 / \mathrm{mL}$ of MTT $(5 \mathrm{mg} / \mathrm{mL})$. Following a further incubation of the plate at $37{ }^{\circ} \mathrm{C}$ for $4 \mathrm{hr}$, the formazan crystals were dissolved in $1 \mathrm{~mL}$ of the solubilization solution ( $50 \mathrm{~mL}$ of isopropanol, $0.43 \mathrm{~mL}$ of conc. $\mathrm{HCl}$, and $5 \mathrm{~mL}$ of Triton X 100). The absorbance of samples was read against blank at $570 \mathrm{~nm}$ after $15 \mathrm{~min}$ incubation at $37{ }^{\circ} \mathrm{C}$ using a UV/ Vis. Spectrophotometer (T $80+$, PG Instruments). All experiments were performed at least three times, and the average of the percentage absorbance was plotted against concentration. The concentration of the extract required to inhibit $50 \%$ of cell growth $\left(\mathrm{IC}_{50}\right)$ was then calculated (Scudiero et al. 1988; Van et al. 2011; Alley et al. 1988).

\section{Results:-}

In vitro cytotoxicity analysis of UNSO on DLA, EAC, and normal spleen cells

Cytotoxicity of the UNSO towards DLA, EAC, and the normal spleen cells were assessed in a short-term in vitro assay system. In the case of DLA cells, the UNSO showed a dose-dependent cytotoxicity. The $\mathrm{IC}_{50}$ value obtained was $77 \pm 5.37 \mu \mathrm{g} / \mathrm{mL}$. In the EAC cell population, UNSO showed cytotoxicity with an $\mathrm{IC}_{50}$ value of $100 \pm 1.41$ $\mu \mathrm{g} / \mathrm{mL}$. However, towards primary rat splenocytes, UNSO was comparatively less toxic with an observed $\mathrm{IC}_{50}$ value above $100 \mu \mathrm{g} / \mathrm{mL}$ concentrations (Figure 1).

\section{In vitro antiproliferative activity of UNSO}

Relative cell proliferative activities of cells such as HeLa, HepG2 and HCT-15 cell lines following exposure with UNSO are summarized in Figure 2. All the cells were sensitive to UNSO and cell viability was found to be reduced depending on the dose of oils. In Hela cells, the required concentration of UNSO to induce loss of cell viability by $50 \%$ ( $\mathrm{IC}_{50}$ value) was found to be above $100 \pm 2.35 \mu \mathrm{g} / \mathrm{mL}$. On the other hand, the $\mathrm{IC}_{50}$ values documented with HepG2, HCT-15 and Vero cells following UNSO exposure were $50.30 \pm 1.45,40.0 \pm 1.94$ and $48.05 \pm 2.43 \mu \mathrm{g} / \mathrm{mL}$ respectively.
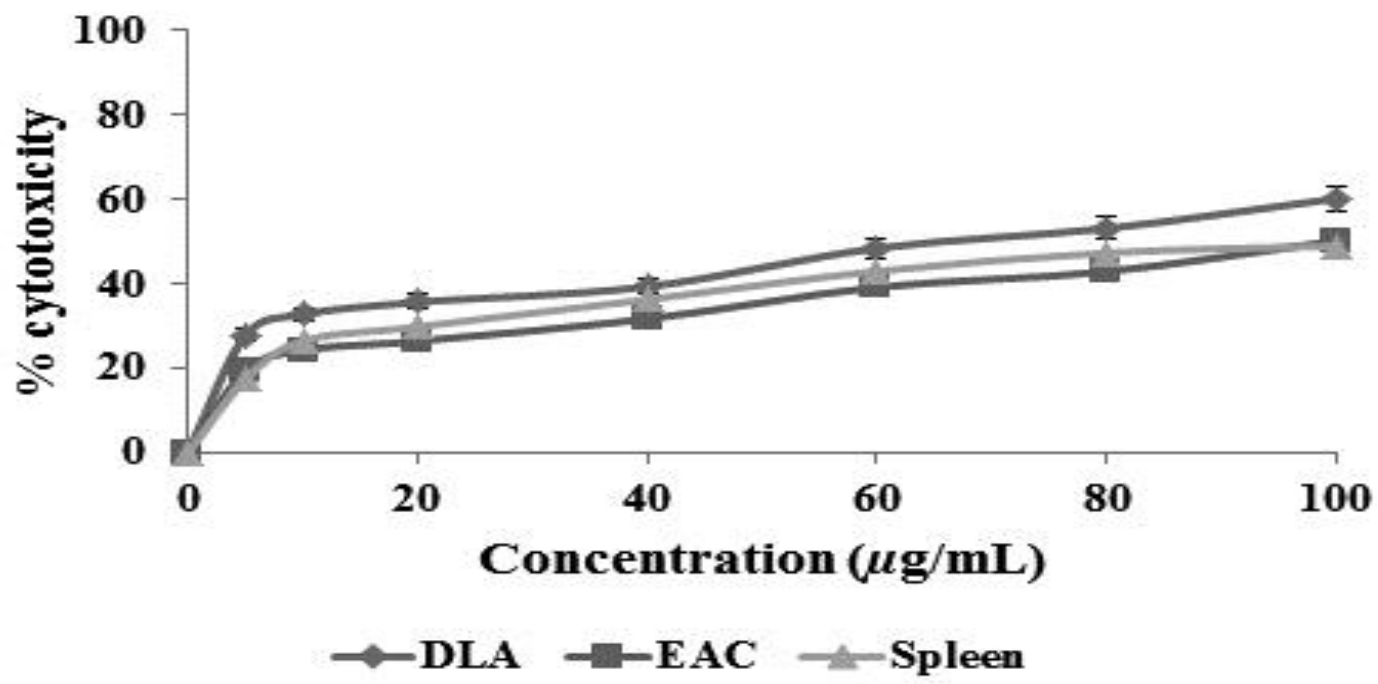

Figure. 1:-In vitro cytotoxicity of U. narum crude seed oil on DLA cells, EAC and normal spleen cells. Cells $\left(1 \times 10^{6}\right.$ cells) suspended in $1 \mathrm{~mL}$ PBS was incubated following the addition of different concentrations of the drugs (indicated in the figure) at $37{ }^{\circ} \mathrm{C}$ for $3 \mathrm{hr}$. About $0.1 \mathrm{~mL}$ of $1 \%$ trypan blue was added at the end of incubation and counted the number of dead cells using hemocytometer. Values are expressed as mean $\pm \mathrm{SD}$ of at least three consecutive experiments. 

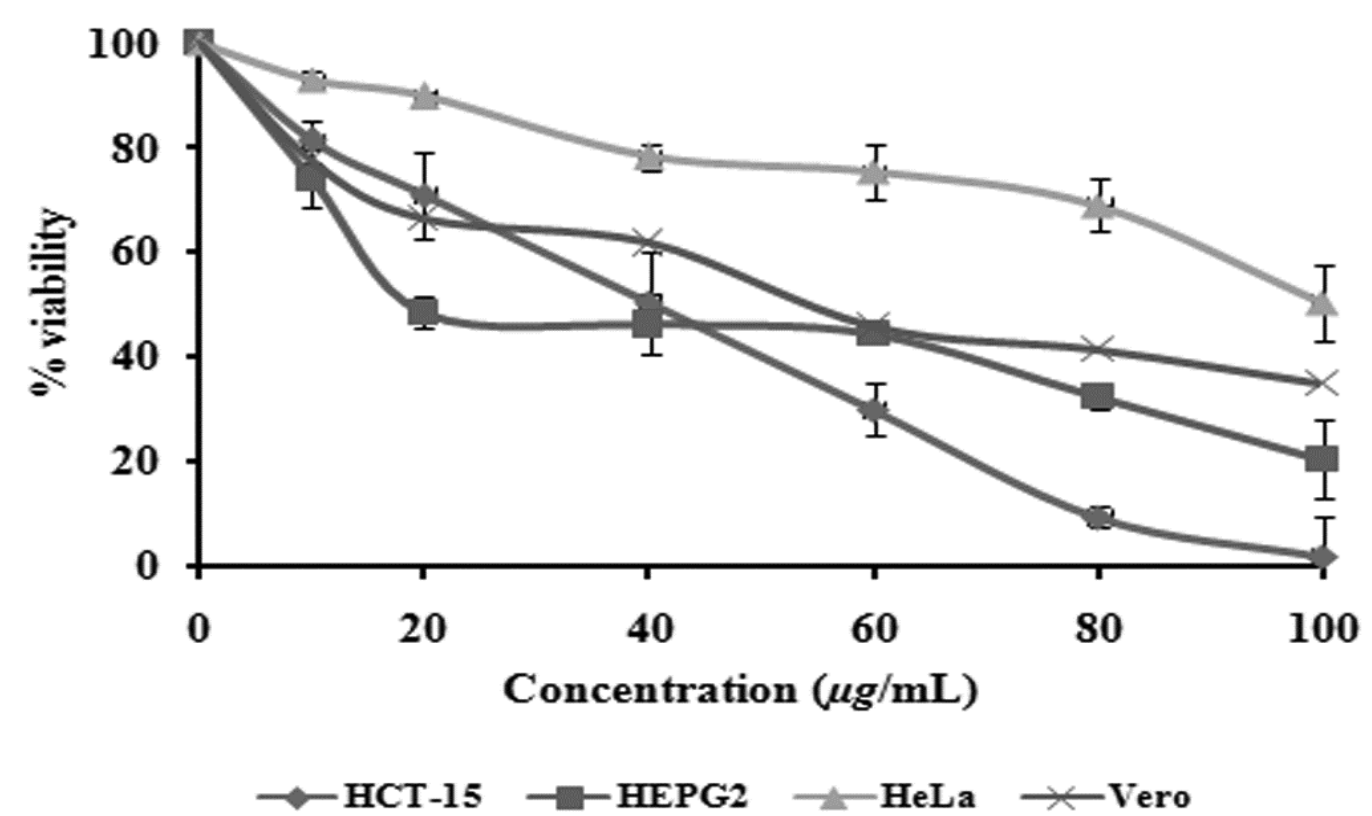

Figure 2:-Growth inhibition by UNSO against HeLa, Vero, HCT-15 and HepG2 cells in culture: Cells $\left(1 \times 10^{5}\right.$ cells $/ \mathrm{mL}$ ) seeded in 12 well plates at $80 \%$ confluent were exposed to various concentration UNSO as indicated in figure and incubated at $37{ }^{\circ} \mathrm{C}$ under a $5 \% \mathrm{CO}_{2}$ and $95 \%$ humid atmosphere for $48 \mathrm{hrs}$. Thereafter the spent medium was replaced with fresh medium containing $100 \mu \mathrm{l} / \mathrm{mL}$ of MTT $(5 \mathrm{mg} / \mathrm{mL})$ and further incubated $4 \mathrm{hr}$, and the formazan crystals were dissolved in $1 \mathrm{~mL}$ of the solubilization solution, read at $532 \mathrm{~nm}$. Values represent means $\pm \mathrm{SD}$ of at least 3 replica cultures.

\section{Discussion:-}

Plants in Annonaceae family are very important due to its medicinal properties and contains a large phytochemical profile. Acetogenin, class of compounds from Annonaceae have shown antitumor efficacy (Miao et al. 2015; Mangal et al. 2015). Several attempts have been made to find out the bioactive compounds present in other species of this family. Uvaria narum is a less explored plant under this family and has been previously reported to contain acetogenins such as isodesacetyluvaricin, squamocin (2\%), uvariamicins I, II and III, Glutinone, glutinol, taraxerol, beta-sitosterol, triterpenes, and benzyl benzoate, Squamocin and panalicin (Padmaja et al. 1993).

In the present study, UNSO exhibits dose-dependent toxicity towards neoplastic cells such as DLA and EAC cells in short duration. However, under the same conditions, the toxicity of UNSO is found to be lower towards primary spleen cells. This observation is significant as spleen cell represent the population of immune cells. Many of the currently using chemotherapeutic drugs have a significant immune suppressive effect. In view of this, it is assumed that the differential toxic potential of UNSO may be an advantage. Cells in cultures have a proliferating population which is shown to be inhibited by UNSO. The growth of almost all cells tested including normal neoplastic cells experienced dose-dependent growth arrest. This suggests the antiproliferative potential of UNSO. At present, no information is available on the chemical nature of compounds present in the UNSO or on the mechanistic basis of its toxicity which need to be evaluated further.

Our study demonstrates the potential cytotoxic and antiproliferative properties of Uvaria narum seed oil. The present analysis suggests that UNSO can be an important source of promising lead compounds in order to contribute to cancer prevention and cancer therapy, however, in future extensive in-vivo studies in animal models will be needed to provide insight for the lead in drug development. 


\section{Reference:-}

1. AlleyMC, Scudiero DA, Monks A, Hursey ML, Czerwinski MJ, Fine DL, Abbott BJ, Mayo JG, Shoemaker RH, Boyd MR (1988) Feasibility of drug screening with panels of human tumor cell lines using a microculture tetrazolium assay. Cancer Res 48 (3):589-601

2. Bissery MC, Vrignaud P, Lavelle F, Chabot GG (1996) Preclinical antitumor activity and pharmacokinetics of irinotecan (CPT-11) in tumor-bearing mice. Ann N Y Acad Sci 803:173-180

3. Cole JR, Torrance SJ, Wiedhopf RM, Arora SK, Bates RB (1976) Uvaretin, a new antitumor agent from Uvaria acuminata (Annonaceae). J Org Chem 41 (10):1852-1855

4. Dai Y, Harinantenaina L, Brodie PJ, Callmander MW, Randrianaivo R, Rakotonandrasana S, Rakotobe E, Rasamison VE, Shen Y, TenDyke K, Suh EM, Kingston DG (2012) Antiproliferative acetogenins from a Uvaria sp. from the Madagascar dry forest. J Nat Prod 75 (3):479-483

5. Demain AL, Vaishnav P (2011) Natural products for cancer chemotherapy. Microbial Biotechnology 4 (6):687699. doi:10.1111/j.1751-7915.2010.00221.x

6. Mangal M, Khan MI, Agarwal SM (2015) Acetogenins as Potential Anticancer Agents. Anticancer Agents Med Chem 16 (2):138-159

7. Miao Y, Xu X, Yuan F, Shi Y, Chen Y, Chen J, Li X (2015) Four cytotoxic annonaceous acetogenins from the seeds of Annona squamosa. Nat Prod Res 16:1-7

8. Mukherjee AK, Basu S, Sarkar N, Ghosh AC (2001) Advances in cancer therapy with plant-based natural products. Curr Med Chem 8 (12):1467-1486

9. Padmaja V, Thankamany V, Hisham A (1993) Antibacterial, antifungal and anthelmintic activities of root barks of Uvaria hookeri and Uvaria narum. J Ethnopharmacol 40 (3):181-186

10. Reddy LJ, Jose B, Jalli RD, Gopu S (2012) Evaluation of antibacterial and DPPH radical scavenging activities of the leaf essential oil and leaf extracts of Uvaria narum (Dunal) Wall. International Journal of Research in Pure and Applied Microbiology 2 (2):7

11. Scudiero DA, Shoemaker RH, Paull KD, Monks A, Tierney S, Nofziger TH, Currens MJ, Seniff D, Boyd MR (1988) Evaluation of a soluble tetrazolium/formazan assay for cell growth and drug sensitivity in culture using human and other tumor cell lines. Cancer Res 48 (17):4827-4833

12. Van MJ, Kaspers GJ, Cloos J (2011) Cell sensitivity assays: the MTT assay. Methods Mol Biol 731:237-245

13. Yang S, Yu J, Xu L (2000) Chemical constituents of Annonaceae plants and their antitumor activities. Zhongguo Yi Xue Ke Xue Yuan Xue Bao 22 (4):376-382 